\title{
AESTHETIC CHARACTERISTICS OF GREEK ORNAMENTAL STONES ASSOCIATED WITH MINERAL, GEOCHEMICAL AND STRUCTURAL PROPERTIES
}

\author{
Badouna I. ${ }^{1^{*}}$, Koutsovitis P. ${ }^{2^{*}}$, Laskaridis K. ${ }^{3^{*}}$, Patronis M. ${ }^{4^{*}}$ and Papatrechas \\ Ch. $^{5^{*}}$ \\ ${ }^{1}$ Geologist, MSc, ioannabad@hotmail.com, ${ }^{2}$ Geologist,Ph.D., petroskoutsovitis@yahoo.com, \\ ${ }^{3}$ Geologist, Ph.D., laskaridis@igme.gr, ${ }^{4}$ Mining Eng., Ph.D., patronis@igme.gr,
}

${ }^{5}$ Geologist,Ph.D., papatrechas@windowslive.com

*Institute of Geology and Mineral Exploration, 1st Spirou Louis St., Olympic Village, 13677, Acharnae, Greece

\begin{abstract}
Commercial marble are almost ready-to-use materials with a high economic value for the building-construction industry. The most important ornamental stones in Greece include limestone and marble with notable qualitative features and are considered products of high commercial value. In this research, seventy-three carbonate samples (limestones, dolomites and marbles) from all over Greece have been studied to determine their macroscopic and petrographic features and to investigate their mineral chemistry and geochemistry. Their colors vary from whitish to gray due to their content of calcite and dolomite, black due to bitumens, yellow due to the presence of iron oxides and clay, red due to iron oxides and mixed phases of calcite-siderite, green-brownish due to the presence of iron oxides or muscovite and chlorite, giving schistosity to the rock. Scattered calcite and dolomite veins, as well as the occurrence of other minerals such as barite, epidote and magnetite, contribute to specific features, thus making their appearance unique. The particular characteristics of each stone depend highly upon the type of minerals present, their composition, grain size and extent of aggregation, their geochemistry and structure. Keywords: Ornamental stones, marble, aesthetic features, mineral chemistry, geochemistry.
\end{abstract}

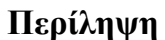

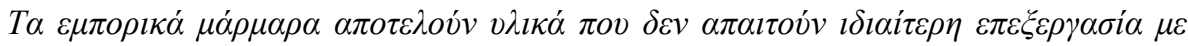

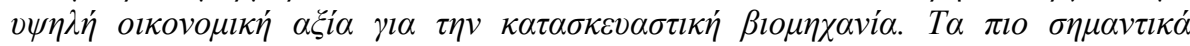

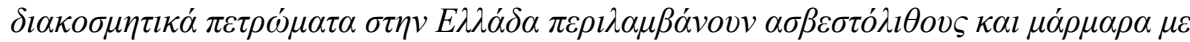

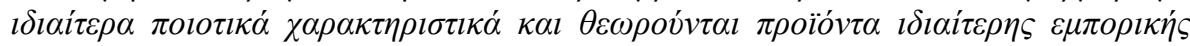

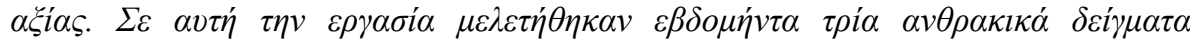

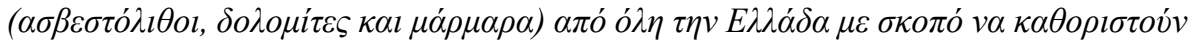

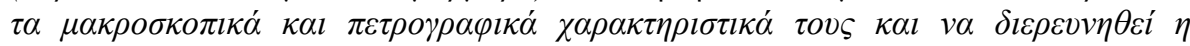

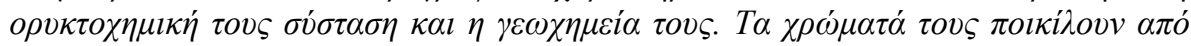

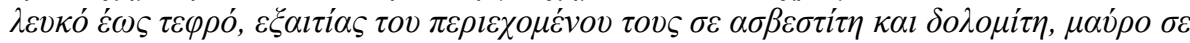

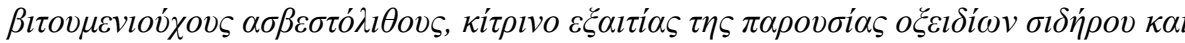

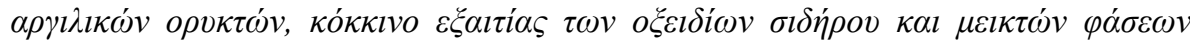




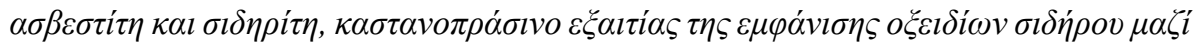

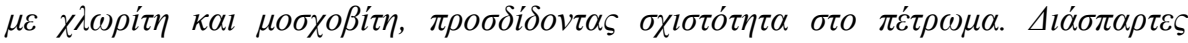

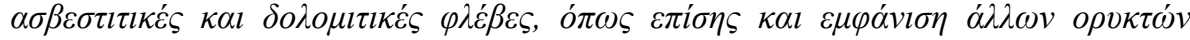

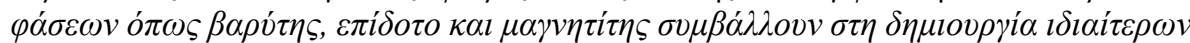

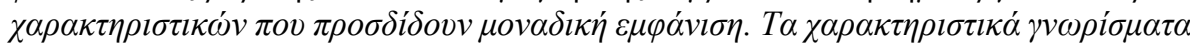

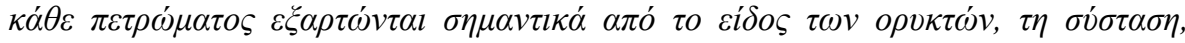

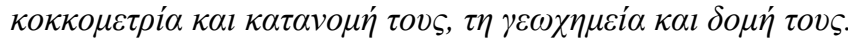

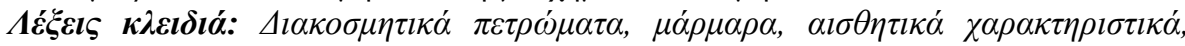

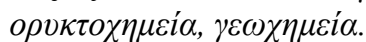

\section{Introduction}

The aesthetic characteristics of marbles depend on their color variability, as well as on their mineralogy and physical features (texture, grain size and other structural features). These parameters can change even within the same pit environment causing color differences in quarried marble blocks. Differences in material content and metamorphic processes influence the final colors of marbles, whereas impurities in the original rock mass also contribute in the different color varieties. Iron-oxides in original rock mass for example result in forming yellow, yellowish or reddish marble types. Manganese-oxides and carbonic impurities in original rock mass cause the formation of dark bluish, violet or black colored marbles. After metamorphism, marbles as rock masses have not stayed static in their locations and they have been influenced by all types of structural defects. Most of the defects in marble mass involve discontinuities, some of which are open, disturbing the continuity of the marble blocks and others are filled with loose or compact materials. Compact filling materials cause color changes and provide additional structural features affecting marble appearance. The marble aesthetic characteristics are directly linked with their commercial final market price, which is decided by marble users and interior designers. (Brilli et al., 2015; Directory of Greek Ornamental and Structural Stones, 2015; Ferrini et al., 2012; Munyanyiwa et al., 1988; Papatrechas, 2011).

In general commercial marbles include many others non-carbonate rocks capable of taking a polish. These rocks such as limestones, travertines, dolomites, marbles, granites, basalts, schists, sandstones, etc. are mined for the construction industry, especially to be used as decorative stones. In Greece, marble industry is one of the most effective forces in economy. In this paper, we present the aesthetic features of characteristic ornamental marbles from many areas of Greece in relation to their petrographic, mineralogical, chemical, and geochemical data.

\section{Sampling and analytical methods}

In this study, 73 samples have been analysed for mineralogical and geochemical investigations. For this purpose, 17 samples were collected from Eastern Macedonia, 6 samples from Central Macedonia, 4 samples from Western Macedonia, 9 samples from Peloponnesus, 4 samples from Thessaly, 1 samples from North Aegean, 2 samples from South Aegean, 7 samples from Crete, 15 samples from Sterea Ellada, 2 samples from Western Greece and 6 samples from Epirus.

Mineralogic and petrographic parameters (i.e. mineral association, grain size and structure, texture of samples) were examined under polarized light microscope using thin sections as well as with scanning electron microscopy-energy dispersive spectroscopy (SEM-EDS), using a JEOL JSM 5600 scanning electron microscope, equipped with an automated energy dispersive analysis system ISIS 300 OXFORD, with the following operating conditions: $20 \mathrm{kV}$ accelerating voltage, $0.5 \mathrm{nA}$ beam current, $20 \mathrm{~s}$ time of measurement and $5 \mu \mathrm{m}$ beam diameter.

Qualitative mineralogical composition of the marble samples was determined with X-ray powder diffraction (XRD), using a Philips X'Pert Panalytical X-ray diffractometer, operating with Cu radiation at $40 \mathrm{kV}, 30 \mathrm{~mA}, 0.020^{\circ}$ step size and $1.0 \mathrm{sec}$ step time. The XRD patterns were evaluated using the DIFFRAC plus EVA software v.11 (Bruker-AXS, USA) based on the ICDD Powder Diffraction File 
(2006). Major oxides and the trace elements analysis of all samples was carried out in the IGME laboratory. Samples were pulverized to $<200$ mesh in an agate mill, were digested with a mixture of $\mathrm{HCl}-\mathrm{HNO}_{3}-\mathrm{HF}$ acids and were analyzed for a series of trace elements by Inductively Coupled PlasmaAtomic Emission Spectroscopy (ICP-MS) and for major elements by X-ray fluorescence (XRF).

\section{Mineralogical and petrographic characterization of the samples}

\subsection{Macroscopic examination}

Macroscopic investigations revealed that the marble samples can be grouped into eight types based on colo $r$ features, crystal size, crystal boundaries and foliation. These groups are identified as (i) white, (ii) semi-w hite - light gray, (iii) beige-yellow, (iv) pink, (v) red, (vi) greenish, (vii) gray and (viii) blackish marbles.Th e ornamental marbles can be classified into three groups, based on their petrological characteristics . These groups are identified as marbles (AM_1- 17, KM_1-2, DM_1-4, P_1-2, TH_1-4, NA_12, STE_1-8, K_1-2), limestones (KM_3-6, P_3-6, BA_1, P_7, STE_9-11, DS_1-2, H_1-6, K_37) and dolomites (P_8-9, STE_12-15).

\subsection{Microscopic and XRD examination}

Microscopically, the marble groups display homeoblastic or heteroblastic mosaic texture, with vary ing crystal size. Larger crystal sizes appear in marbles from Macedonia, South Aegean and Sterea Ellada (cipolin marbles). The limestone-dolomite groups display a homeoblastic or heteroblastic te xture, with small crystal sizes.

Calcite and dolomite represent the major crystalline phases of the studied samples. Other minerals that participate in the mineralogical composition are quartz, muscovite, biotite, clinochlore, chlorit e, epidote, clay minerals (illite, kaolinite), magnetite, apatite, fluorite, sphalerite, etc. Calcite is the main mineral in samples AM_5, AM_8-11, AM_13, KM_1-6, DM_1-4, P_1-7, BA_ $1, \quad \mathrm{~T} \mathrm{H}_{-} 1-4, \quad \mathrm{~N} \mathrm{~A}_{-} 1-2, \quad \mathrm{~S} \mathrm{~T} \mathrm{E} \_1-11, \quad \mathrm{D} \mathrm{S}_{-} 1-2, \mathrm{H}_{-} 1-6, \mathrm{~K}_{-} 1-$ 7, while dolomite is the main mineral in samples AM_1-4, AM_6-7, AM_14-17, P_8-9, STE_12-1 5. Calcitic marbles mainly consist of $75-100 \%$ calcite and $0-20 \%$ dolomite, dolomitic marbles cons ist of $88-99 \%$ dolomite and $1-12 \%$ calcite, limestones consist of $85-100 \%$ calcite and $1 \%$ dolomite, and dolomites consist of $90-96 \%$ dolomite and 3-10\% calcite. Calcite bearing rocks (both marbles and limestones) may also contain up to $15 \%$ micas.

The color presented by a marble, depends on its composition or its granulometry. White, semi-whit $\mathrm{e}$, light gray and beige colors can be attributed either to pure calcite or dolomite. For example, the c alcitic marble NA_1 consists of 100\% calcite (Fig. 1.1), while the dolomitic marble AM_3 consists mainly of dolomite (white crystalline mass), while calcite crystals are concentrated at few faint gra y areas (Fig. 1.2). At the semi-white calcite marble DM_3, the white crystalline mass consists of ca lcite and the gray strips consist of dolomite crystals with smaller size (Fig. 1.3). In the white calciti c marble DM_1, the white crystalline mass consists of calcite with granoblastic texture and the yell ow strips consist of smaller size calcite crystals mixed with clay minerals (Fig. 1.4). In the yellowwhite calcitic marble AM_15, the crystalline mass comprises of small dolomitic crystals and a net work of yellow-red veins mainly of iron and manganese oxides (Fig. 1.5). Beige-yellow colors usu ally indicate the presence either of clay minerals or iron oxides. Pink and red marbles mainly attrib ute their color to iron and manganese impurities in the mass of calcite or dolomite, as calcium or $\mathrm{m}$ agnesium are substituted by these elements. In the pink calcitic marble TH_2, the crystalline mass consists of pink calcitic crystals of various sizes (Fig. 1.6), while the green-black veins consist of $\mathrm{m}$ uscovite, epidote and metallic minerals. In the red limestone STE_9 the color is attributed to the dif fusion of iron oxides in the micritic calcitic mass (Fig. 1.7). Green marbles on the other hand, like $t$ he green cipolin marble STE_4, owe their darkest green color to layers of mica, epidote, titanite an d metallic minerals (Fig. 1.8). Blackish marbles like dolomite P_9 and limestone KM_3, owe their color to the presence of bitoumens (Fig. 1.9, 1.10). Moreover, in sample KM_3 concentrated micro crystals of iron-manganese oxides replace calcitic fossils (Fig. 1.10). 


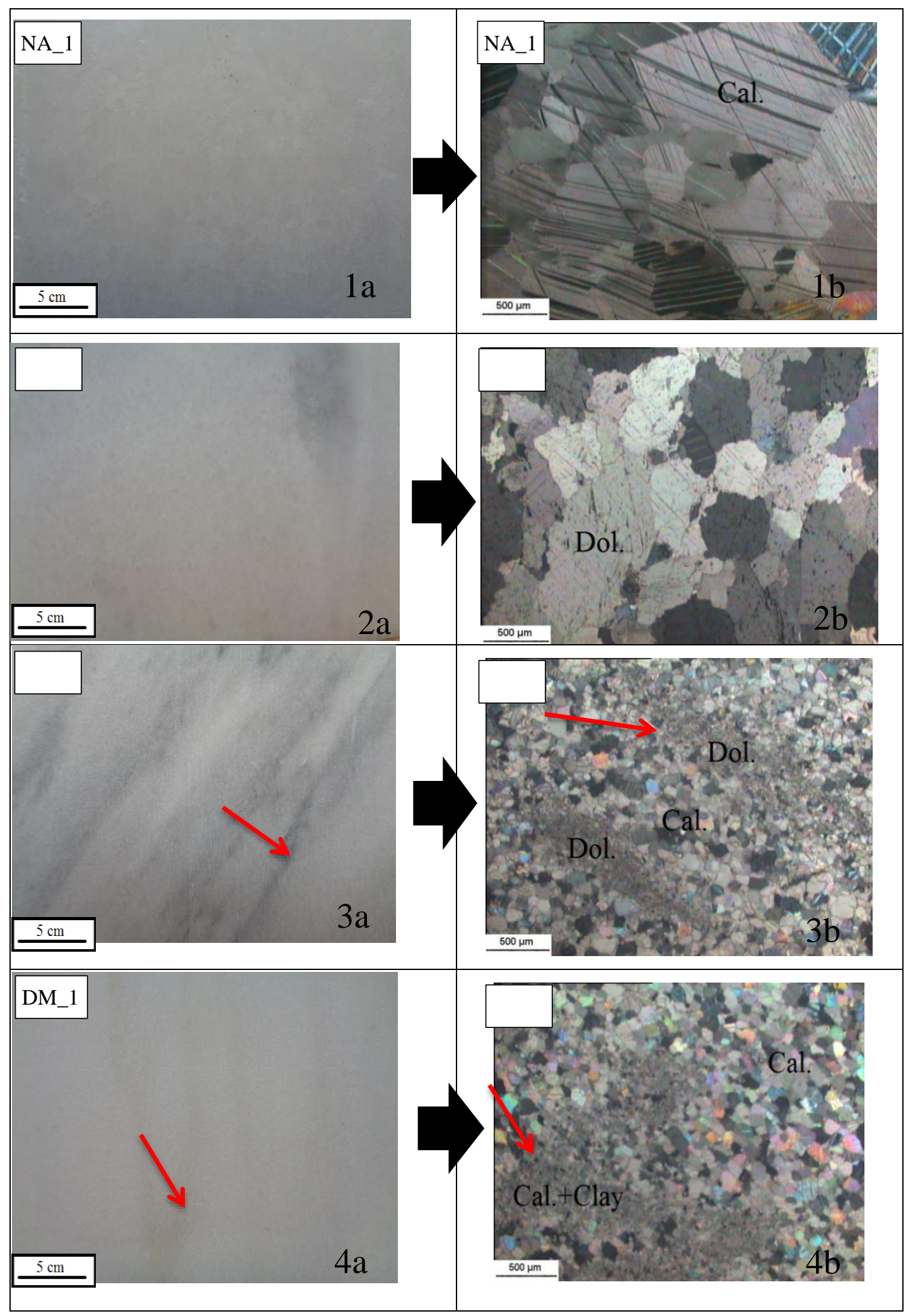




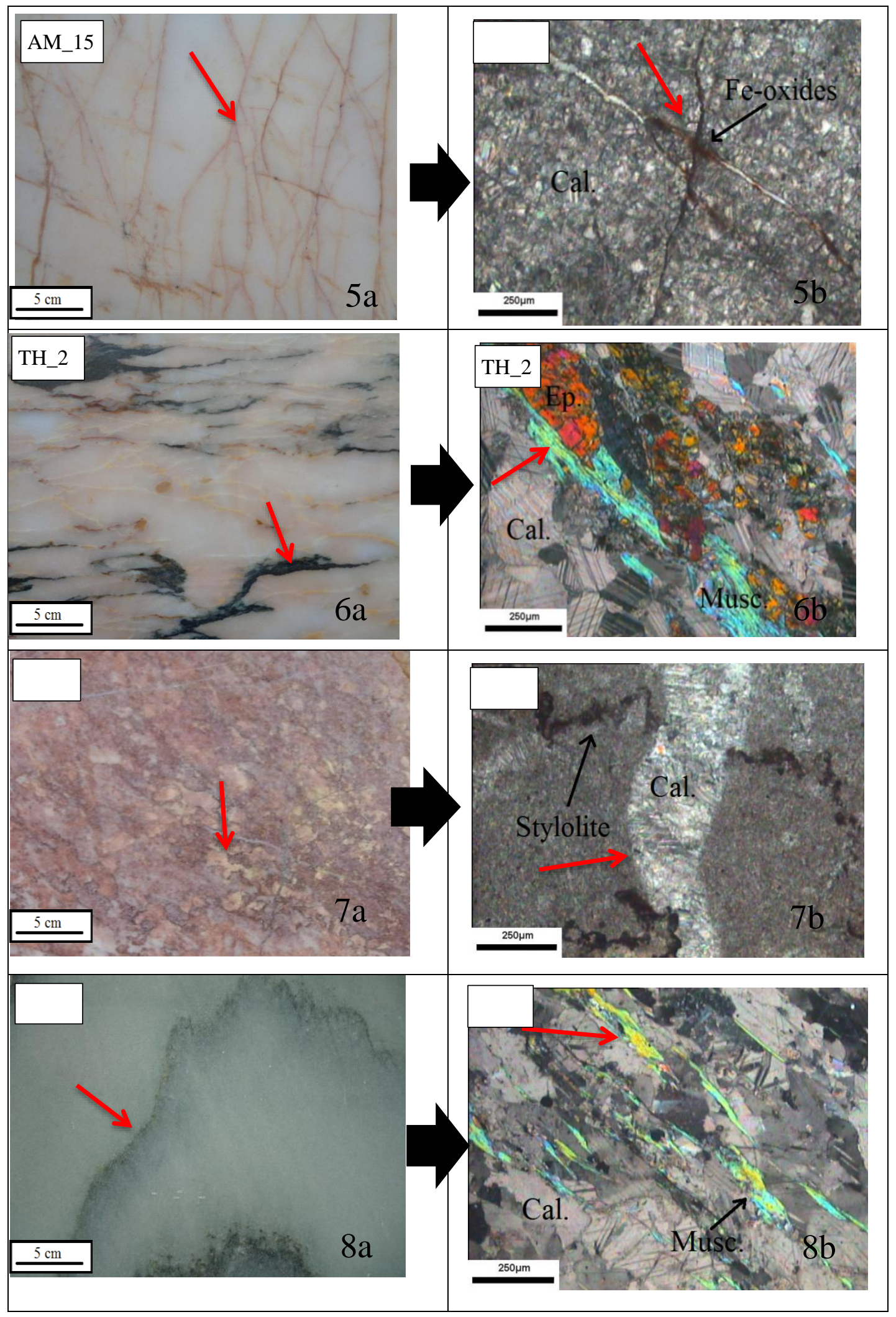




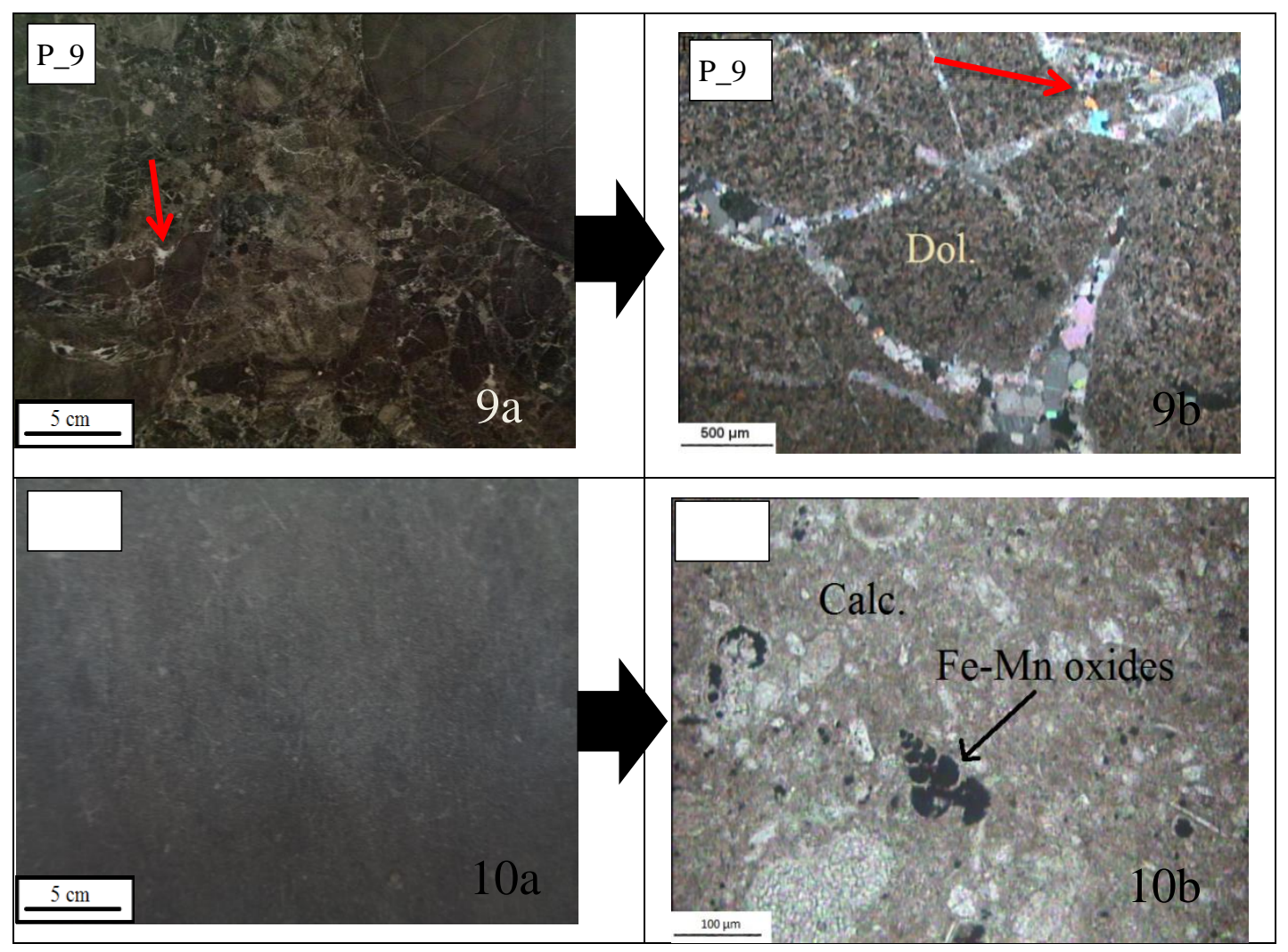

Figure 1 - Macroscopic image of the marble to the left and corresponding microscopic image of the marble to the right; calcitic marble NA_1 (1), dolomitic marble AM_3 (2), dolomitic-calcitic marble DM_3 (3), calcitic marble DM_1 (4), calcitic marble AM_15 (5), calcitic marble TH_2 (6), limestone STE_9 (7), cipolin marble STE_4 (8), dolomite P_9 (9), limestone KM_3 (10).

\section{Geochemical analysis of the samples}

Chemical analysis was performed in order to emphasize the differences or similarities in major and trace element trends between the marble groups studied. Major and trace element analyses results are given in table 1. Binary diagrams of the analyzed samples are shown in figure 3. In general, all marble groups display similar compositional distribution in terms of major oxide and trace element s. In this paper representative analyses of some samples are presented.

It is evident that all carbonate samples exhibit limited presence of major elements except $\mathrm{Ca}$ and $\mathrm{Mg}$. The $\mathrm{Mn}, \mathrm{Ba}$ and $\mathrm{Sr}$ elements and element ratios (i.e $\mathrm{Mg} / \mathrm{Ca}, \mathrm{Mn} / \mathrm{Sr}, \mathrm{Ca} / \mathrm{Sr}$ ) are much more useful than major elements alone for determining the geochemical affinities of rock (Koralaya et al., 2016; Lazzarini et al., 1980; Melezhik et al., 2001; Melezhik et al., 2008; Murra et al., 2011; Bağc1 et al., 2010). In relatively pure marbles, the amounts of $\mathrm{SiO} 2$ and $\mathrm{Al} 2 \mathrm{O} 3$ are very low and those of $\mathrm{TiO} 2$, $\mathrm{Na} 2 \mathrm{O}$ and $\mathrm{K} 2 \mathrm{O}$ are almost lacking. From the binary plots, it is shown a positive correlation between $\mathrm{Na}$ and $\mathrm{K}$ which is attributed to the limited presence of feldspars (Fig. 3g). All cipolin marbles are rich in Mn (STE_4, STE_5, STE_6, STE_7 and TH_4), a fact that is attributed to layers of mica and epidote crystals between calcitic crystals. Limestones from Epirus region (H_1-6), a limestone from Western Greece (DS-2) and limestones and marbles from Crete (K_1-4, K_7) are also Mn-rich. Cr3+ with ionic radius $0.62 \AA$ substitutes $\mathrm{Fe} 3+(0.65 \AA)$. Chromium is an element mainly connected to ultramafic rocks, especially in the grid of chromite or chromium silicate minerals (such as the chrome mica fuchsite). Samples from Peloponnesus (P_4, P_2, P_7), Thessaly (TH_3, TH_4) and central Macedonia (KM_3), appear to be rich in $\mathrm{Cr} 3+$. In the binary plots, there is a positive correlation between $\mathrm{Ni}$ and $\mathrm{Cr}$ observed 
in the calcitic marbles, whereas in the dolomitic rocks the content of Ni does not seem to play any significant role in the extended presence of $\mathrm{Cr}$. Dolomitic rocks contain minerals such as spinel in a standard amount; hence $\mathrm{Ni}$ and $\mathrm{Cr}$ cannot exceed a specific value. Moreover, there is a positive correlation between $\mathrm{Cu}$ and $\mathrm{Zn}$ in the calcitic marbles, whereas in the dolomitic rocks there is no statistically significant correlation between those two elements. As in the case of spinel, other similar heavy minerals that contain $\mathrm{Cu}$ and $\mathrm{Zn}$ have also a specific value range in dolomitic rocks.
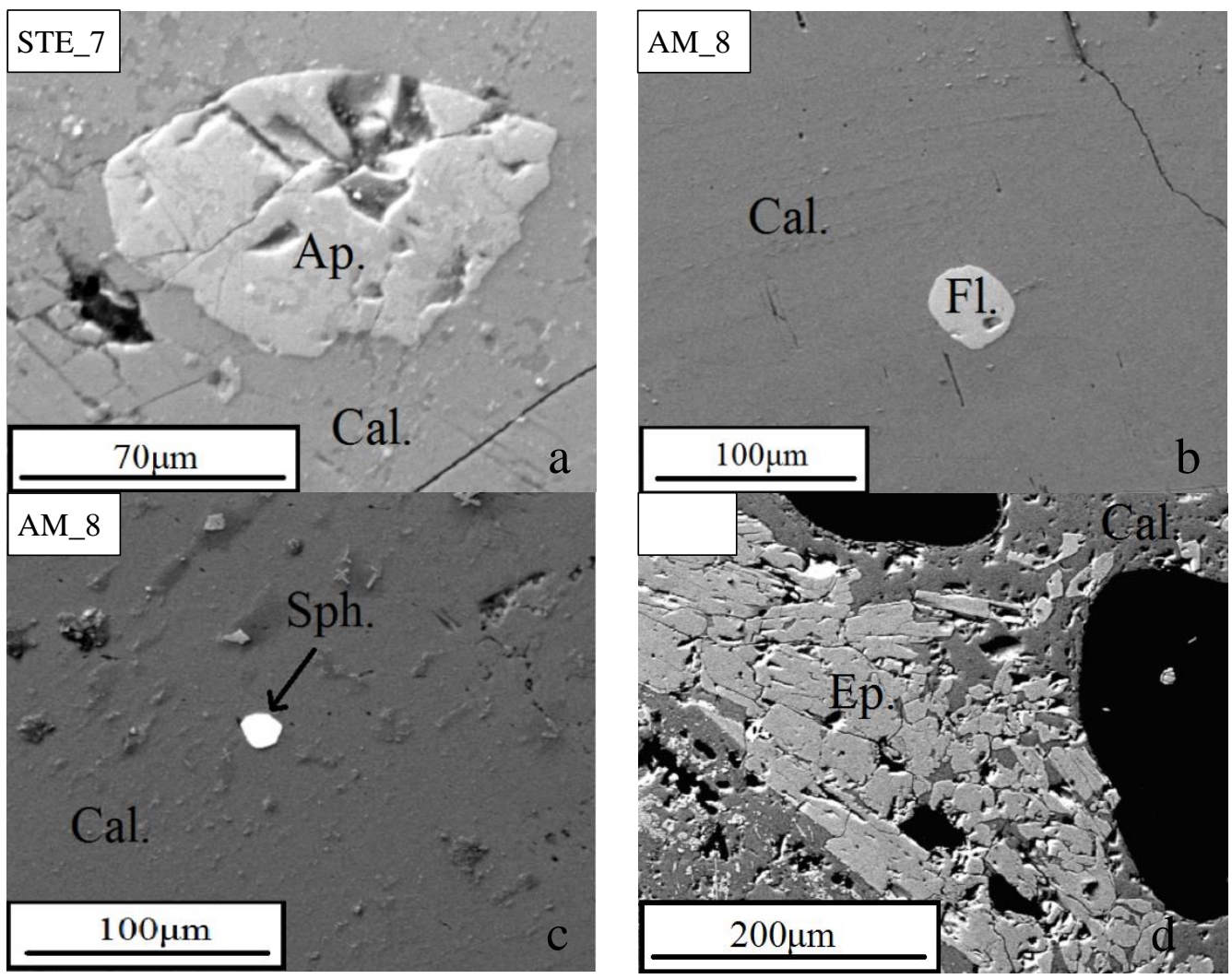

Figure 2 - SEM microphotographs of marble samples. Minerals such as apatite (sample STE_7a), fluorite (sample AM_8b), sphalerite (sample AM_8c) and epidote (sample TH_2d) participate also in the mineral composition of the samples.

High Sb content occurs in limestone sample from western Greece (DS_1: 6 ppm). Extremely high Ba co ntent has been found in samples from Sterea Ellada (calcitic-dolomitic marble STE_1: 4800 ppm, dolom ite STE_13: $6000 \mathrm{ppm}$ ) and in samples from Crete (dolomitic limestone K_5: 4200 ppm, calcitic marble K_1: $1600 \mathrm{ppm}$ ). As it is shown in the binary plots, there is a positive correlation between $\mathrm{Ba}$ and As, both in calcitic and dolomitic rocks, whereas there is no statistical correlation between $\mathrm{Ba}$ and $\mathrm{Sr}$.

Strontium usually substitutes the $\mathrm{Ca}$ ions in dolomites due to its similar ion size. Thus it is expected that dolomitic rocks will present lower Sr contents than the calcitic rocks. Furthermore, the value range of $\mathrm{Sr}$ in calcitic rocks is higher than that in dolomitic, whereas marbles exhibit lower $\mathrm{Sr}$ value range compared to the non-metamorphic rocks (limestones, dolomites). Strontium is an indicator of diagenetic recrystallization in natural carbonate rocks. Its content decreases during dolomitisation and the subsequent replacement of calcite by dolomite (Shearman and Shirmohammadi, 1969; Garde, 1979). In addition, marbles that are in contact with schists tend to have slightly enriched $\mathrm{Sr}$ contents. The $\mathrm{Sr} / \mathrm{Ca}$ ratio in seawater, the sedimentation environment, and biogenic factors affect strontium separation in biogenic carbonates and control the $\mathrm{Sr} / \mathrm{Ca}$ ratio in marine carbonate rocks (Stoll and Schrag, 2001). Elements such as $\mathrm{K}, \mathrm{Na}, \mathrm{Rb}$, and $\mathrm{Sr}$ are reported to be mobilized during sedimentation and 
metamorphism. Since elements such as Th, Sc, and Y are least affected during sedimentation, they give more reliable information on the source properties (Chen et al., 2002). The highest Rb contents appear in limestones (samples KM_5: 92 ppm, K_3: 92 ppm) and in calcitic marbles (sample K-5: 175 ppm). Rb easily substitutes $\mathrm{K}^{+}$due to its chemical behavior and ion size $\left(\mathrm{Rb}^{+}: 1.52 \AA, \mathrm{K}^{+}: 1.38 \AA\right.$ ), so although $\mathrm{Rb}^{+}$ does not form groundless minerals, it easily replaces $\mathrm{K}^{+}$in biotite and $\mathrm{K}$-feldspars (Iliadou et al., 2004).

Table 1 - Chemical composition of representative samples.

\begin{tabular}{|c|c|c|c|c|c|c|c|}
\hline wt.\% & AM_13 & STE_5 & AM_17 & AM_6 & H_5 & P_6 & STE_13 \\
\hline $\mathrm{SiO}_{2}$ & $<0.10$ & 4.20 & 0.18 & $<0.10$ & 0.35 & $<0.05$ & 0.30 \\
\hline $\mathrm{Al}_{2} \mathrm{O}_{3}$ & $<0.10$ & 0.84 & 0.05 & $<0.10$ & 0.08 & $<0.05$ & 0.00 \\
\hline $\mathrm{Fe}_{2} \mathrm{O}_{3}$ & $<0.10$ & 0.61 & 0.05 & $<0.10$ & 0.20 & $<0.05$ & 0.31 \\
\hline $\mathrm{CaO}$ & 54.80 & 52.15 & 32.80 & 30.90 & 53.80 & 54.00 & 35.10 \\
\hline $\mathrm{MgO}$ & $<0.05$ & 0.80 & 19.80 & 21.10 & 0.30 & 0.65 & 17.80 \\
\hline $\mathrm{MnO}$ & $<0.05$ & 0.05 & $<0.05$ & $<0.05$ & $<0.05$ & $<0.05$ & 0.00 \\
\hline $\mathrm{TiO}_{2}$ & $<0.10$ & $<0.05$ & $<0.05$ & $<0.10$ & $<0.05$ & $<0.05$ & $<0.05$ \\
\hline $\mathrm{K}_{2} \mathrm{O}$ & 0.20 & 0.29 & 0.11 & 0.28 & 0.07 & 0.02 & 0.08 \\
\hline $\mathrm{Na}_{2} \mathrm{O}$ & 1.06 & 0.32 & 0.65 & 1.09 & 0.35 & 1.30 & 0.39 \\
\hline $\mathrm{LOI}$ & 42.81 & 41.10 & 45.15 & 46.24 & 43.50 & 42.44 & 46.80 \\
\hline ppm & \multicolumn{7}{|c|}{} \\
\hline $\mathrm{Cr}$ & 25.00 & 26.00 & 6.00 & 24.00 & 11.00 & 45.00 & 28.00 \\
\hline $\mathrm{Mn}$ & 15.00 & 425.00 & 7.00 & 12.00 & 135.00 & 65.00 & 35.00 \\
\hline $\mathrm{Ni}$ & 13.00 & 26.00 & 10.00 & 8.00 & 16.00 & 30.00 & 24.00 \\
\hline $\mathrm{Cu}$ & 2.30 & 40.00 & 3.00 & 2.00 & 32.00 & 7.00 & 41.00 \\
\hline $\mathrm{Zn}$ & 14.00 & 28.00 & 4.00 & 21.00 & 26.00 & 25.00 & 53.00 \\
\hline $\mathrm{As}$ & 1.50 & 1.50 & 1.00 & 1.30 & 2.00 & 2.00 & 370.00 \\
\hline $\mathrm{Sr}$ & 150.00 & 430.00 & 20.00 & 16.00 & 385.00 & 158.00 & 220.00 \\
\hline $\mathrm{Ba}$ & 28.00 & 75.00 & 12.00 & 6.00 & 38.00 & 67.00 & 6000.00 \\
\hline $\mathrm{AM} 13 \& \mathrm{STE} 5=$ calcitic marbles, AM_17 \& AM_6= dolomitic marbles ,dolo \\
\hline
\end{tabular}

\section{Conclusions}

Samples of ornamental stones from different areas of Greece are examined. They are classified into three main categories: marbles (calcitic and dolomitic), limestones and dolomites. Particular emphasis is given on the correlation between mineralogical composition and aesthetic characteristics. The constituents that are responsible for these special features are the Fe-Mn oxides and silicate minerals such as quartz, muscovite, biotite, clinochlore, chlorite, epidote, clay minerals (illite, kaolinite), etc. Oxides are either diffused to the whole rock mass or are concentrated in veins, while the silicate minerals usually appear in strips or agglomerates. Moreover, the geochemical characteristics of the marble groups show that those which have undergone higher diagenetic processes (i.e. calcitic and dolomitic marbles) exhibit lower $\mathrm{Sr}$ contents in comparison to nonmetamorphic rocks (limestones and dolomites). Taking into consideration the fact that $\mathrm{Sr}$ substitutes only $\mathrm{Ca}$, it is expected that all types of calcite-dominant rocks contain more Sr compared to the dolomitic ones. Positive correlations between $\mathrm{Ba}$ and As are observed in all studied groups, whereas there is no statistical correlation between $\mathrm{Ba}$ and $\mathrm{Sr}$. Furthermore, it is concluded that dolomitic rocks show specific value ranges in their composition of the elements $\mathrm{Ni}, \mathrm{Cr}, \mathrm{Cu}$ and $\mathrm{Zn}$, which cannot be correlated, while calcitic rocks show positive correlation and no limitation in their content. All these features affect marble appearance and contribute to their commercial final market price Considering also the fact that many of these ornamental stones have been used in architecture from ancient times as ornamental or building materials (statues, temples, emperors' residences, etc.), further investigation and research is required in order to enrich the existing database and archaeometric data which will be of immense importance for archeological and geoscience scientific fields. 

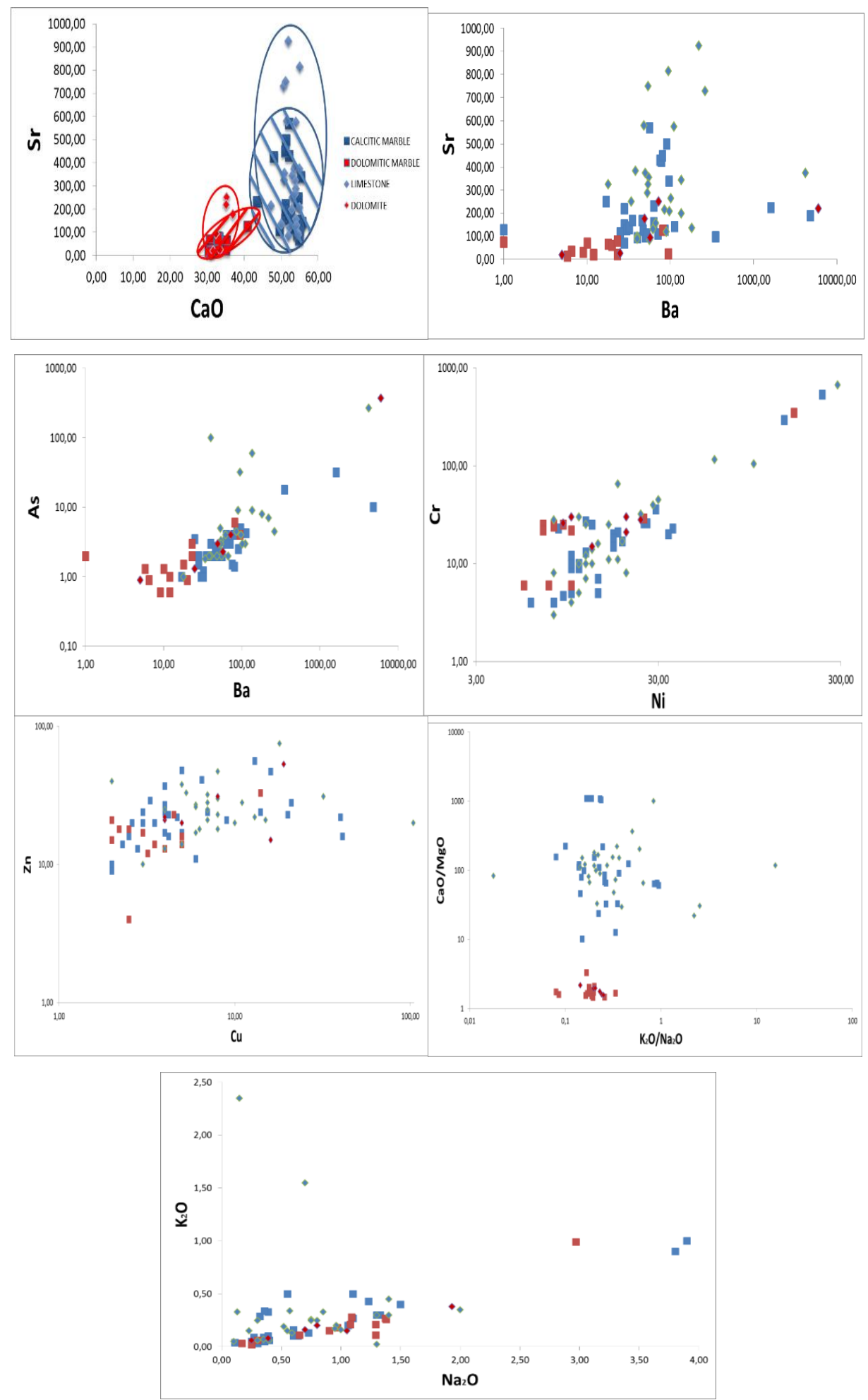

Figure 3 - Binary diagrams of analyzed samples. $\mathrm{CaO}-\mathrm{Sr}(\mathrm{a})$, $\mathrm{Ba}-\mathrm{Sr}(\mathrm{b})$, Ba-As (c), $\mathrm{Ni}-\mathrm{Cr}$ (d), $\mathrm{Cu}-\mathrm{Zn}(\mathrm{e}), \mathrm{K}_{2} \mathrm{O} / \mathrm{Na}_{2} \mathrm{O}-\mathrm{CaO} / \mathrm{MgO}$ (f), $\mathrm{Na}_{2} \mathrm{O}-\mathrm{K}_{2} \mathrm{O}$ (g). The legend of the first diagram is valid for all diagrams. 


\section{Acknowledgments}

The authors express their sincere appreciation to I.G.M.E. and to its Director of Mineral Natural Resources Department Dr. George Economou for allowing them to examine the samples at the laboratories of Mineral Natural Resources Department. They also thank Yiannis Kouseris, Nikos Xirokostas, Efi Tsapara, Pantelis Patsis and Michalis Sakalis for their laboratory support. The study was funded by "Research And Evaluation Of Selected, Non-Energy, Primary Raw Materials Of The State, Aiming At The Sustainable Operation Of Mineral Industry (NEPRM)" project.

\section{References}

Bağcı, M., Kibici, Y., Yıldız, A. and Akıncı, Ö.T., 2010. Petrographical and geochemical investigation of the Triassic marbles associated with Menderes Massif metamorphics, Kavaklidere, Mugla, SW Turkey, J. Geochem. Explor., 107, 39-55.

Brilli M., Giustini F., Conte A., Mercadal P., Quarta G., Plumed H., Scardozzi G. and Belardi, G., 2015. Petrography, geochemistry, and cathodoluminescence of ancient white marble from quarries in the southern Phrygia and northern Caria regions of Turkey: Considerations on provenance discrimination, J. of Archaeological Science, 4, 124-142.

Chen, B., Jahn, B.-M. and Wei, C.-J., 2002. Petrogenesis of Mesozoic granitoids in the Dabie UHP complex, central China: trace element and Nd-Sr isotope evidence, Lithos, 60, 67-88.

Directory of Greek Ornamental \& Structural Stones, I.G.M.E., 2015.

Ferrini, V., De Vito, C., Mignardi, S. and Fucinese, D., 2012. Archaeological carved slabs of the Langobard art in churches of Peligna Valley and Spoleto (Italy): provenance of the stones, $J$. of Archaeological Science, 39, 3505-3515.

Garde, A.A., 1979. Strontium geochemistry and carbon and oxygen isotopic compositions of lower Proterozoic dolomite and calcite marbles from the Marmoliric formation, West Greenland. Precambrian Research, 8, 183-199.

Iliadou, S., Tsirambidis, A., Kasoli- Fournaraki, A. and Michailidis, K., 2004. Petrographic and geochemical research of the carbonate rocks of the area of Vafiochori, Kilkis, Bull. Geol. Soc. Greece, 36(1), 10-18.

Koralaya, T. and Kilıncarslan, S., 2016. A multi-analytical approach for determining the origin of the marbles in Temple-A from Laodicea ad Lycum (Denizli-Western Anatolia, Turkey), J. Cultural Heritage, 42-52.

Lazzarini, L., Moschini, G. and Stievano, B.M., 1980. A contribution to the identification of Italian, Greek and Anatolian marbles through a petrological study and the evaluation of $\mathrm{Ca} / \mathrm{Sr}$ ratio, Archaeometry, 22, 173-182.

Melezhik, V.A., Gorokhov, I., Fallick, A.F. and Gjelle, S., 2001. Strontium and carbon isotope geochemistry applied to dating of carbonate sedimentation: an example from high-grade rocks of the Norwegian Caledonides, Precambrian Research, 108, 267-292.

Melezhik, V.A., Bingen, B., Fallick, A.F., Gorokhov, I.M., Kuznetsov, A.B, Sandstad, J.S., Solli, A., Bjerkgard, T., Henderson, I., Boyd, R., Jamal, D. and Moniz, A., 2008. Isotope chemostratigraphy of marbles in northeastern Mozambique apparent depositional ages and regional implications, Precambrian Research, 162, 540-558.

Munyanyiwa, H. and Hanson, R., 1988. Geochemistry of marbles and calc-silicate rocks in the PanAfrican Zambezi belt, Zambia, Precambrian research, 38, 177-200.

Murra, J., Bawo, K., Galindo, C., Casquet, C., Pankhurst, R., Rapela, C. and Dahlquist, J., 2011. Sr, $\mathrm{C}$ and $\mathrm{O}$ isotope composition of marbles from the Sierra de Ancasti, Eastern Sierras Pampeanas, Argentina: age and constraints for the Neoproterozoic-Lower Paleozoic evolution of the proto-Gondwana margin, Geol. Acta, 9, 1-23.

Papatrechas, Ch., 2011. Correlation of physicomechanical properties with grain size and mineralogical composition of the carbonate rocks of Eastern Macedonia (Greece), PhD Thesis, University of Thessaloniki.

Shearman, D.J. and Shirmohammadi, N.H., 1969. Distribution of strontium in dedolomites from the French Jura, Nature, 223, 606-608.

Stoll, H.M. and Schrag, D.P., 2001. Coccolith $\mathrm{Sr} / \mathrm{Ca}$ as a new indicator of coccolithophorid calcification and growth rate, Geochem. Geophys. Geosyst., 1, 1-24. 